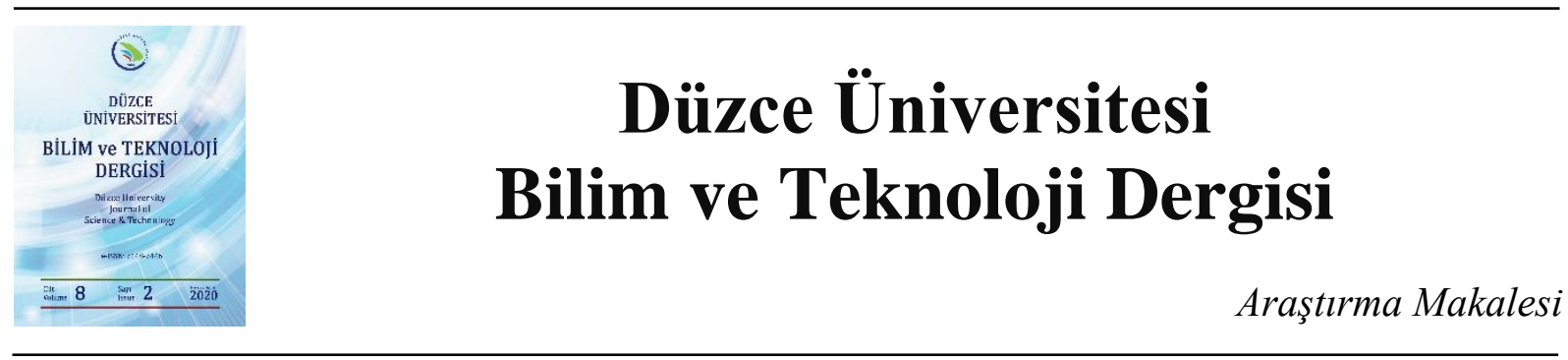

\section{N,N'-Bis(Salisiliden)-1,3-Propandiamin Schiff Bazının Agregasyon Kaynaklı Emisyon Artışı}

\author{
(iD) Ece ERGUN ${ }^{\mathrm{a}, *}$, (D) Ümit ERGUN ${ }^{\mathrm{b}}$ \\ ${ }^{a}$ Ölçüm ve Analiz Hizmetleri GB Birimi, Ürün ve Hizmetler Şubesi Müdürlüğü, Radyasyon ve Hızlandırıcı \\ Teknolojileri Dairesi Başkanlı̆̆̆, Türkiye Atom Enerjisi Kurumu, Ankara, TÜRKİYE \\ ${ }^{b}$ Kimya Bölümü, Fen Edebiyat Fakültesi, Düzce Üniversitesi, Düzce, TÜRKİYE \\ * Sorumlu yazarın e-posta adresi: ece.ergun@taek.gov.tr
}

DOI: $10.29130 /$ dubited.656807

\begin{abstract}
ÖZET
$\mathrm{Bu}$ çalışmada, N,N'-bis(salisiliden)-1,3-propandiamin Schiff bazından hazırlanan çözeltilerin agregasyon kaynaklı emisyon artış özelliği incelenmiştir. Ligandın iki farklı çözücü ile farklı konsantrasyonlarda çözeltileri hazırlanmış ve bu çözeltilere değişik yüzdelerde (\%1-50) su eklenmiştir. Schiff bazının etanol ile hazırlanmış $2 \times 10^{-4} \mathrm{M}^{\prime}$ lık çözeltisinde, su derişimi arttıkça emisyon dalgaboyunun kırmızıya kaydı̆̆ 1 ve floresans şiddetinin arttığı görülmüştür. Ayrıca, bu çözeltilerin floresans özelliklerinin zamana bağlı olarak değişimi incelenmiştir. Yapılan çalı̧̧malar sonucunda, Schiff bazının, etanol içindeki su safsızlığının kalitatif ve kantitatif olarak belirlenmesinde kullanılabileceği öne sürülmüştür.
\end{abstract}

Anahtar Kelimeler: Schiff bazl, Agregasyon kaynaklı emisyon, Floresans

\section{Aggregation-Induced Emission Enhancement of N,N'-bis (Salicylidene)-1,3-Propanediamine Schiff Base}

\begin{abstract}
In this study, aggregation-induced emission enhancement feature of the solutions prepared from N,N'-bis (salicylidene) -1,3-propanediamine Schiff base was investigated. The ligand solution were prepared at different concentrations with two different solvents and water was added to these solutions at varying percentages (1$50 \%)$. It was observed that emission wavelength was red-shifted and the fluorescence intensity was enhanced, as the concentration of water increased in $2 \times 10^{-4} \mathrm{M}$ ethanolic solution of Schiff base. In addition, time-dependent changes in the fluorescence properties of these solutions were investigated. As a result, it has been suggested that Schiff base can be used for qualitative and quantitative determination of water impurity in ethanol.
\end{abstract}

Keywords: Schiff base, Aggregation-induced emission, Fluorescence 


\section{GIRIS}

Lüminesans özelliği gösteren moleküller, organik 1şık yayan diyot (OLED) [1-3], biyo-görüntüleme [4-8], kemosensör [9-13] vb. alanlarda kullanımlarından dolayı araştırma dünyasında büyük ilgi görmektedir. Bu tür moleküllerin birçoğu seyreltik çözelti ortamında şiddetli floresans özellik sergilese de, agregasyon (kümeleşme) meydana geldiğinde veya katı halde bulunduğunda floresansları azalmakta ya da sönümlenmektedir. Agregasyon kaynaklı sönümleme (Aggregation caused quenching-ACQ) adı verilen bu olay, çözelti konsantrasyonu arttıkça ve/veya çözünürlüğünün az olduğu bir çözücü ortama eklendikçe meydana gelen kümeleşmeden kaynaklanmaktadır $[14,15]$. Agregasyonun, moleküllerin floresans özelliğini azaltması veya sönümlendirmesi ilk defa Förster ve Kasper tarafindan yapılan bir çalışmada ortaya konulmuştur [16]. Bu davranışın birçok aromatik hidrokarbon ve türevleri için geçerli olduğu daha sonraki çalışmalar ile raporlanmış ve bu olgu 1970 yılında Birk tarafından ACQ olarak tanımlanmıştır [17].

Tang ve çalışma grubu tarafından 2001 yılında yayımlanan bir çalı̧̧mada etanol çözeltisi içerisinde floresans özellik göstermeyen bir seri molekülün su eklenmesi sonrasında floresans özellik kazandığ rapor edilmiştir [18]. Çalış1lan moleküllerin, su eklenmesi ile nanopartiküller oluşturduğu, serbest dönme hareketlerinin sınırlanarak daha düzlemsel yapılar oluşturdukları, dolayısıyla da floresans özellik kazandıkları öne sürülmüştür. Tang ve arkadaşları tarafından ilk defa sunulan bu kavram agregasyon kaynakl1 emisyon (Aggregation Induced Emission-AIE) veya agregasyon kaynakl1 emisyon artışı (Aggregation Induced Emission Enhancement-AIEE) olarak literatüre geçmiştir. $\mathrm{Bu}$ tarihten sonra, AIEE hem bilim hem de teknoloji alanında popüler bir araştırma konusuna dönüşmüştür.

Azometinler veya iminler olarak da bilinen Schiff bazları $(\mathrm{RHC}=\mathrm{NR})$, birçok alan için kullanışlı ligand sistemlerinin tasarımında büyük esneklik sunan ve en yaygın kullanım alanına sahip organik bileşikler arasında yer almaktadır. Schiff bazları, primer aminlerin karbonil bileşikleri ile verdiği kondenzasyon reaksiyonu sonucunda oluşan bileşiklerdir. $\mathrm{Bu}$ çalışmada kullanılan N,N'bis(salisiliden)-1,3-propandiamin $\left(\mathrm{LH}_{2}\right)$ Schiff bazının önceki çalışmalarda floresans davranışı ve çeşitli metallerle yaptığ 1 komplekslerin floresans özelliği incelenmiş [19], çinko tayini için kemosensör olarak ve çinko ile oluşturduğu kompleksin biyo-görüntülemede boyar madde olarak kullanılabilirliği tartışılmıştır [12]. Bu çalışmada ise Schiff bazı çözeltisine farklı oranlarda su eklenmesi ile oluşabilecek AIEE özelliği araştırılmıştır.

\section{MALZEME ve YÖNTEM}

\section{A. REAKTIF VE ÇÖZÜCÜLER}

Bu çalışmada kullanılan reaktif ve çözücüler Tablo 1' de verilmiştir.

Tablo 1. Çalıșmada kullanılan reaktif ve çözücüler

\begin{tabular}{cc}
\hline Reaktif/Çözücü Adı & Firma \\
\hline Salisaldehit & Merck \\
\hline 1,3-diaminopropan & Merck \\
\hline Etanol (CHROMASOLV®, for HPLC, $\geq \% 99,9)$ & Sigma Aldrich \\
\hline Asetonitril (CHROMASOLV®, for HPLC, $\geq \% 99,9)$ & Sigma Aldrich \\
\hline Deiyonize Su & Milipore \\
\hline
\end{tabular}




\section{B. SCHIFF BAZININ SENTEZI}

N,N'-bis(salisiliden)-1,3-propandiamin $\left(\mathrm{LH}_{2}\right)$ sentezi için $0,04 \mathrm{~mol}(4,88 \mathrm{~g})$ salisaldehit $50 \mathrm{~mL}$ sicak etanolde çözüldü, hazırlanan bu çözeltiye $0,02 \mathrm{~mol}$ (1,48 g) 1,3-diaminopropan ilave edildi. Karışım kaynama noktasına kadar isıtıldıktan sonra 3-4 saat oda sıcaklığında bekletildi. Elde edilen sarı kristaller süzüldükten sonra havada kurutuldu [20]. Bu ligandın sentezine ait reaksiyon Şekil 1'de verilmiştir.

2<smiles>O=Cc1ccccc1O</smiles>

salisaldehit<smiles>CCN=Cc1ccccc1O</smiles>

$\mathrm{N}, \mathrm{N}$-bis(salisiliden)-1,3-diaminopropan $\left(\mathrm{LH}_{2}\right)$

Şekil 1. $N, N^{\prime}$-bis(salisiliden)-1,3-diaminopropan $\left(\mathrm{LH}_{2}\right)$ sentezine ait reaksiyon

\section{B. ÇÖZELTILERINN HAZIRLANMASI VE ANALITIIK YÖNTEM}

Sentezlenen Schiff bazının $\left(\mathrm{LH}_{2}\right)$ etanol ve asetonitril ile ayrı ayrı $4 \times 10^{-2}$ M'lık stok çözeltileri hazırlandı. Bu çözeltilerden uygun seyreltmeler yapılarak $4 \times 10^{-3} \mathrm{M}^{\prime}{ }^{\prime} 1 \mathrm{k}$ çözeltiler elde edildi. Ligandın AIEE özelliğini incelemek amacıyla, bu çözeltilere uygun miktarlarda deiyonize su ilave edilerek floresans ölçümleri için \%0-90 su içeriğine sahip 10 mL'lik çalışma çözeltileri hazırlandı. Çalışma çözeltilerinin hazırlanması Tablo 2'de verilmiştir.

Bu çalışmada yapılan floresans ölçümleri Agilent Cary Eclipse floresans spektrofotometre cihazı ile gerçekleştirildi. Uyarma-emisyon dalgaboyları ve ölçümler sırasında ayarlanan monokromotörlerin slit aralığı değerleri "Bulgular ve Tartışma" bölümünde ilgili kısımlarda verilmiştir.

\section{BULGULAR VE TARTIȘMA}

$\mathrm{Bu}$ çalışmada kullanılan Schiff bazı $\left(\mathrm{LH}_{2}\right)$ suda çok az çözünürken etanol, metanol gibi protik çözücülerde orta derecede, asetonitril, DMSO, DMF gibi aprotik çözücüler içerisinde ise oldukça fazla miktarda çözünmektedir. Literatür araştırmasına göre farklı moleküllerin AIEE davranışları, bu molekülleri iyi çözen çözücü ortamında hazırlanmış olan çözeltilerine farklı miktarlarda su eklenmesi sonucu floresans değişimleri ölçülerek bulunmuştur [18,21-26]. Buna göre, bu çalışmada $\mathrm{LH}_{2}$ 'yi çözmek için protik çözücü olarak etanol, aprotik çözücü olarak ise asetonitril seçilerek farklı çözücü tiplerinin ligandın AIEE özelliği üzerine etkisi incelenmiştir. Bu çözücüler kullanılarak iki farklı derişimde $\left(4 \times 10^{-2}\right.$ ve $\left.4 \times 10^{-3} \mathrm{M}\right)$ stok çözeltileri hazırlanarak ligandın AIEE davranışının konsantrasyona bağlı değişimi de araştırılmıştır. Bu amaçla, stok çözeltilerden uygun seyreltmeler ve su ilaveleri (Tablo 2) yapılarak ligand derişimi $2 \times 10^{-3}$ ve $2 \times 10^{-4} \mathrm{M}$ olan ve farklı oranda su içeriğine sahip etanol ve asetonitril çözeltileri kullanılmıştır.

\section{A. ÖN DENEYLER}

Çalışmada, öncelikle, ön deneme deneyleri gerçekleştirilmiştir. Ön deneme çalışmalarında \%0, 1, 2, 5 , $10,20,50,70$ ve 90 su içeren çözeltiler kullanılmıştır. Daha önceki çalışmada $\mathrm{LH}_{2}$ 'nin etanol ortamındaki çözeltisinin $\left(1 \times 10^{-5} \mathrm{M}\right)$ uyarma dalgaboyu $350 \mathrm{~nm}$ olarak bulunmuştur [12]. Bu nedenle, bu çalışmada kullanılan farklı derişimde ve farklı çözücü ortamında hazırlanmış olan $\mathrm{LH}_{2}$ çözeltilerinin uyarma dalgaboyları 300-450 nm aralığında ön tarama yapılarak tespit edilmiştir. 
Tablo 2. Çalışma çözeltilerinin hazırlanması

\begin{tabular}{|c|c|c|c|c|c|}
\hline $\begin{array}{l}\text { Çalışma } \\
\text { çözeltisi }\end{array}$ & $\begin{array}{l}\text { LH2 stok } \\
\text { çözelti } \\
\text { derişimi } \\
(M)\end{array}$ & $\begin{array}{c}\text { LH2 stok } \\
\text { çözeltisinden } \\
\text { alınan hacim } \\
(m L) \\
\end{array}$ & $\begin{array}{c}\text { Eklenen } \\
\text { (asetonitril/etanol) } \\
\text { çözücü hacmi } \\
(\mathrm{mL})\end{array}$ & $\begin{array}{l}\text { Eklenen } \\
\text { su hacmi } \\
\quad(m L)\end{array}$ & $\begin{array}{c}\text { Çalışma çözeltisindeki } \\
\text { LH2 ve su derişimleri } \\
(M)(\%)\end{array}$ \\
\hline 1 & $4 \times 10^{-2} / 4 \times 10^{-3}$ & 0,5 & 9,5 & 0 & $\begin{array}{c}\mathrm{LH}_{2}=2 \times 10^{-3} / 2 \times 10^{-4} \\
\mathrm{Su}=0\end{array}$ \\
\hline 2 & $4 \times 10^{-2} / 4 \times 10^{-3}$ & 0,5 & 9,4 & 0,1 & $\begin{array}{c}\mathrm{LH}_{2}=2 \times 10^{-3} / 2 \times 10^{-4} \\
\mathrm{Su}=1\end{array}$ \\
\hline 3 & $4 \times 10^{-2} / 4 \times 10^{-3}$ & 0,5 & 9,3 & 0,2 & $\begin{array}{c}\mathrm{LH}_{2}=2 \times 10^{-3} / 2 \times 10^{-4} \\
\mathrm{Su}=2\end{array}$ \\
\hline 4 & $4 \times 10^{-2} / 4 \times 10^{-3}$ & 0,5 & 9,2 & 0,3 & $\begin{array}{c}\mathrm{LH}_{2}=2 \times 10^{-3} / 2 \times 10^{-4} \\
\mathrm{Su}=3\end{array}$ \\
\hline 5 & $4 \times 10^{-2} / 4 \times 10^{-3}$ & 0,5 & 9,1 & 0,4 & $\begin{array}{c}\mathrm{LH}_{2}=2 \times 10^{-3} / 2 \times 10^{-4} \\
\mathrm{Su}=4\end{array}$ \\
\hline 6 & $4 \times 10^{-2} / 4 \times 10^{-3}$ & 0,5 & 9,0 & 0,5 & $\begin{array}{c}\mathrm{LH}_{2}=2 \times 10^{-3} / 2 \times 10^{-4} \\
\mathrm{Su}=5\end{array}$ \\
\hline 7 & $4 \times 10^{-2} / 4 \times 10^{-3}$ & 0,5 & 8,9 & 0,6 & $\begin{array}{c}\mathrm{LH}_{2}=2 \times 10^{-3} / 2 \times 10^{-4} \\
\mathrm{Su}=6\end{array}$ \\
\hline 8 & $4 \times 10^{-2} / 4 \times 10^{-3}$ & 0,5 & 8,8 & 0,7 & $\begin{array}{c}\mathrm{LH}_{2}=2 \times 10^{-3} / 2 \times 10^{-4} \\
\mathrm{Su}=7\end{array}$ \\
\hline 9 & $4 \times 10^{-2} / 4 \times 10^{-3}$ & 0,5 & 8,7 & 0,8 & $\begin{array}{c}\mathrm{LH}_{2}=2 \times 10^{-3} / 2 \times 10^{-4} \\
\mathrm{Su}=8\end{array}$ \\
\hline 10 & $4 \times 10^{-2} / 4 \times 10^{-3}$ & 0,5 & 8,6 & 0,9 & $\begin{array}{c}\mathrm{LH}_{2}=2 \times 10^{-3} / 2 \times 10^{-4} \\
\mathrm{Su}=9\end{array}$ \\
\hline 11 & $4 \times 10^{-2} / 4 \times 10^{-3}$ & 0,5 & 8,5 & 1 & $\begin{array}{c}\mathrm{LH}_{2}=2 \times 10^{-3} / 2 \times 10^{-4} \\
\mathrm{Su}=10\end{array}$ \\
\hline 12 & $4 \times 10^{-2} / 4 \times 10^{-3}$ & 0,5 & 7,5 & 2 & $\begin{array}{c}\mathrm{LH}_{2}=2 \times 10^{-3} / 2 \times 10^{-4} \\
\mathrm{Su}=20\end{array}$ \\
\hline 13 & $4 \times 10^{-2} / 4 \times 10^{-3}$ & 0,5 & 6,5 & 3 & $\begin{array}{c}\mathrm{LH}_{2}=2 \times 10^{-3} / 2 \times 10^{-4} \\
\mathrm{Su}=30\end{array}$ \\
\hline 14 & $4 \times 10^{-2} / 4 \times 10^{-3}$ & 0,5 & 5,5 & 4 & $\begin{array}{c}\mathrm{LH}_{2}=2 \times 10^{-3} / 2 \times 10^{-4} \\
\mathrm{Su}=40\end{array}$ \\
\hline 15 & $4 \times 10^{-2} / 4 \times 10^{-3}$ & 0,5 & 4,5 & 5 & $\begin{array}{c}\mathrm{LH}_{2}=2 \times 10^{-3} / 2 \times 10^{-4} \\
\mathrm{Su}=50\end{array}$ \\
\hline 16 & $4 \times 10^{-2} / 4 \times 10^{-3}$ & 0,5 & 2,5 & 7 & $\begin{array}{c}\mathrm{LH}_{2}=2 \times 10^{-3} / 2 \times 10^{-4} \\
\mathrm{Su}=70\end{array}$ \\
\hline 17 & $4 \times 10^{-2} / 4 \times 10^{-3}$ & 0,5 & 0,5 & 9 & $\begin{array}{c}\mathrm{LH}_{2}=2 \times 10^{-3} / 2 \times 10^{-4} \\
\mathrm{Su}=90\end{array}$ \\
\hline
\end{tabular}

Tarama spektrumları incelendiğinde, ligand derişimi ve çözücü tipi değiş̧tikçe \%0-90 su içeren çözeltilerin uyarma dalgaboylarının değişmekte olduğu görülmüş̧ür. Tablo 3'de bu çözeltiler için maksimum uyarma dalgaboyları sıralanmıştır.

Ligand konsantrasyonu $2 \times 10^{-4} \mathrm{M}$ olan su eklenmemiş (\%0 su) etanol ve asetonitril ile hazırlanmış çözeltilerin maksimum uyarma dalgaboyları incelendiğinde etanollü çözeltinin dalgaboyunun asetonitril ile hazırlanan çözeltiye göre bir miktar kırmızıya kaydığı görülmektedir. Etanol protik bir çözücü olduğundan uyarılmış durumdaki ligand molekülleri ile güçlü hidrojen bağları oluşturmaktadır. $\mathrm{Bu}$ durumda, $\pi-\pi^{*}$ geçişi için gerekli enerji azalmış ve uyarma dalgaboyu kırmızıya kaymıştır. Aynı ligand konsantrasyonuna $\left(2 \times 10^{-4} \mathrm{M}\right)$ ancak farklı derişimde su içeriğine sahip çözeltilerin tarama sonuçlarına göre; $\% 0-50$ su içeriğine sahip etanollü çözeltilerde uyarma dalgaboyları su konsantrasyonu arttıkça kırmızıya kaymış, \%50 sulu çözeltilerde bu kayma maksimum noktasına ulaşmış $(375 \mathrm{~nm})$ ve su oranı $\% 70$ ve 90 olan etanollü çözeltilerde de aynı uyarma dalgaboyu (375 $\mathrm{nm})$ tespit edilmiştir. Buna karşılık, asetonitril ile hazırlanmış olan \%0-50 su içeriğine sahip olan çözeltilerin dalgaboyu aynı $(350 \mathrm{~nm})$ olup kırmızıya kayma ancak \%70 ve 90 sulu çözeltilerde 
gözlenmiştir (360 nm). Buna göre, çözeltilerdeki su derişimine bağlı olarak maksimum uyarma dalgaboyundaki kırmızıya kayma agregasyon oluşumuna işarettir.

Tablo 3. Ön deneme çalışmalarında kullanılan farklı yüzdelerde su içeren çözeltilerin uyarma dalgaboyları

\begin{tabular}{|c|c|c|c|c|c|c|c|}
\hline \multicolumn{4}{|c|}{$\left[\mathrm{LH}_{2}\right]=2 \times 10^{-4} \mathrm{M}$} & \multicolumn{4}{|c|}{$\left[\mathrm{LH}_{2}\right]=2 \times 10^{-3} \mathrm{M}$} \\
\hline \multicolumn{2}{|c|}{ Etanol } & \multicolumn{2}{|c|}{ Asetonitril } & \multicolumn{2}{|c|}{ Etanol } & \multicolumn{2}{|c|}{ Asetonitril } \\
\hline $\begin{array}{c}\text { Su oranı } \\
(\%)\end{array}$ & $\begin{array}{c}\text { Uyarma } \lambda \\
(\mathrm{nm})\end{array}$ & $\begin{array}{c}\text { Su oranı } \\
(\%)\end{array}$ & $\begin{array}{c}\text { Uyarma } \lambda \\
(\mathrm{nm})\end{array}$ & $\begin{array}{c}\text { Su oranı } \\
(\%)\end{array}$ & $\begin{array}{c}\text { Uyarma } \lambda \\
(\mathrm{nm})\end{array}$ & $\begin{array}{c}\text { Su oranı } \\
(\%)\end{array}$ & $\begin{array}{c}\text { Uyarma } \lambda \\
(n m)\end{array}$ \\
\hline 0 & 353 & 0 & 350 & 0 & 360 & 0 & 360 \\
\hline 1 & 354 & 1 & 350 & 1 & 360 & 1 & 360 \\
\hline 2 & 356 & 2 & 350 & 2 & 360 & 2 & 360 \\
\hline 5 & 360 & 5 & 350 & 5 & 360 & 5 & 360 \\
\hline 10 & 365 & 10 & 350 & 10 & 360 & 10 & 360 \\
\hline 20 & 370 & 20 & 350 & 20 & 360 & 20 & 360 \\
\hline 50 & 375 & 50 & 350 & 50 & 352 & 50 & 355 \\
\hline 70 & 375 & 70 & 360 & 70 & 345 & 70 & 345 \\
\hline 90 & 375 & 90 & 360 & 90 & 342 & 90 & 342 \\
\hline
\end{tabular}

Ligand derişimi $2 \times 10^{-3}$ M'a çıkarıldığında \%0-20 su içeriğine sahip etanollü ve asetonitrilli çözeltilerde maksimum uyarma dalgaboyu $360 \mathrm{~nm}$ bulunmuştur. Bu çözeltilerin, $\mathrm{LH}_{2}$ 'nin daha seyreltik çözeltilerine $\left(2 \times 10^{-4} \mathrm{M}\right)$ göre uyarma dalgaboylarının kırmızıya kayması ve çözücü tipine göre dalgaboyunda değişiklik gözlenmemesi, çözeltilerde ligand-çözücü etkileşimlerinden daha çok yüksek konsantrasyon sebebiyle ligand molekülleri arasında etkileşmelerin olduğunu göstermektedir (örneğin dimer/eksimer oluşumu). Çözeltide bulunan su oranı \%50, 70 ve 90'a çıkarıldığında maksimum uyarma dalgaboyları etanollü çözeltiler için sirasıyla 352, 345 ve $342 \mathrm{~nm}$ bulunurken, asetonitrilli çözeltilerde bu değerler ise 355,345 ve $342 \mathrm{~nm}$ olarak tespit edilmiştir. Buna göre, $\mathrm{LH}_{2}$ derişimi $2 \times 10^{-3} \mathrm{M}$ olduğunda, $2 \times 10^{-4} \mathrm{M}^{\prime}$ lık ligand çözeltilerinin tam tersine, yüksek su içeriklerinde uyarma dalgaboyunun maviye kaydığı görülmüştür. Uyarma dalgaboyundaki maviye kaymanın da yine agregasyondan kaynaklandığı düşünülmektedir.

Moleküller katı halde kümeleşmeye başladıklarında genellikle H-tipi veya J-tipi olmak üzere iki farklı tipte agregasyon davranışı gösterirler. H-agregatlarında moleküller ağırlıklı olarak yüz-yüze (paralel veya sandviç tipi), J-agregatlarında ise baş-kuyruk (sıralı) düzeninde istiflenirler [27]. Moleküllerin hangi tipte istifleneceği geometrileri, çözücü polaritesi, sıcaklık gibi parametrelere bağlıdır [28]. Uyarma spektrumlarında, H-tipi agregatların maviye kayma, J-tipi agregatların ise kırmızıya kayma gösterdiği bilinmektedir [27,28]. Bu nedenle, çözeltilerin uyarma dalgaboylarında gözlenen kaymalar agregasyon oluşumunu göstermektedir. Ayrıca, ligand derişimi $2 \times 10^{-3} \mathrm{M}$ olan hem etanol hem de asetonitril ile hazırlanmış $\% 90$ oranında su içeren çözeltilerde gözle görülür bir çökme tespit edilmiştir. $\mathrm{Bu}$ durum da, $\mathrm{LH}_{2}$ çözeltilerinde su eklenmesiyle floresans şiddetinde meydana gelen artışın agregasyondan kaynaklandığını doğrulamaktadır.

$\mathrm{Bu}$ çözeltilerin agregasyon sonucu floresans davranışları gösterip göstermediği, belirlenen dalgaboylarında (Tablo 3) uyarılmaları ile kaydedilen emisyon spektrumlarından tespit edilmiştir. Emisyon spektrumları, çözeltilere su eklenmesinden 30 dakika sonra, uyarma ve emisyon monokromotörlerinin slit aralıkları 5 nm'ye ayarlanarak alınmıştır. Elde edilen spektrumlar Şekil 2'de verilmiştir.

Şekil 2a'dan da görüldüğü üzere, floresans emisyonu en şiddetli olan sulu çözeltiler $\mathrm{LH}_{2}$ derişimi $2 \times 10^{-4} \mathrm{M}$ olan etanol içerisinde hazırlanmış çözeltilerdir. Bu çözeltilerden \%10-90 oranında su içerenler, saf etanollü (\%0 su) ligand çözeltisine göre daha fazla floresans özelliği göstermiştir. Ayrıca 
$\% 0$ su içeren etanollü ligand çözeltisinin maksimum emisyon dalgaboyu $442 \mathrm{~nm}$ iken su içeriği arttıkça emisyon dalgaboyunun kırmızıya kaydığı görülmektedir (Tablo 4). En şiddetli floresans \%50 su içeriğine sahip çözeltide bulunmuş olup emisyon dalgaboyu $498 \mathrm{~nm}$ olarak tespit edilmiştir. Ancak, $\% 70$ ve 90 oranında su içeren çözeltilerin maksimum emisyon gösterdiği dalgaboyu $498 \mathrm{~nm}$ olmasına rağmen emisyon şiddetleri, \%50 sulu çözelti ile karşılaştırıldığında, daha düşüktür. Asetonitril ortamında hazırlanmış çözeltilerde ise $\% 70$ ve 90 oranlarında su içerenler en yüksek floresans şiddeti gösterseler de şiddetleri \%50 su bulunduran etanollü çözeltiye kıyasla düşük bulunmuştur. Bunun yanı sıra, \%50 oranında su içeren asetonitrilli çözeltilerde çok düşük bir floresans emisyonu gözlenmiş, \%0-20 sulu çözeltilerde ise neredeyse hiç emisyon görülmemiştir. $\mathrm{LH}_{2}$ derişimi $10 \mathrm{~kat}$ arttığında $\left(2 \times 10^{-3} \mathrm{M}\right)$ gerek etanollü gerekse asetonitrilli çözeltilerde kayda değer bir floresans şiddeti tespit edilememiştir.

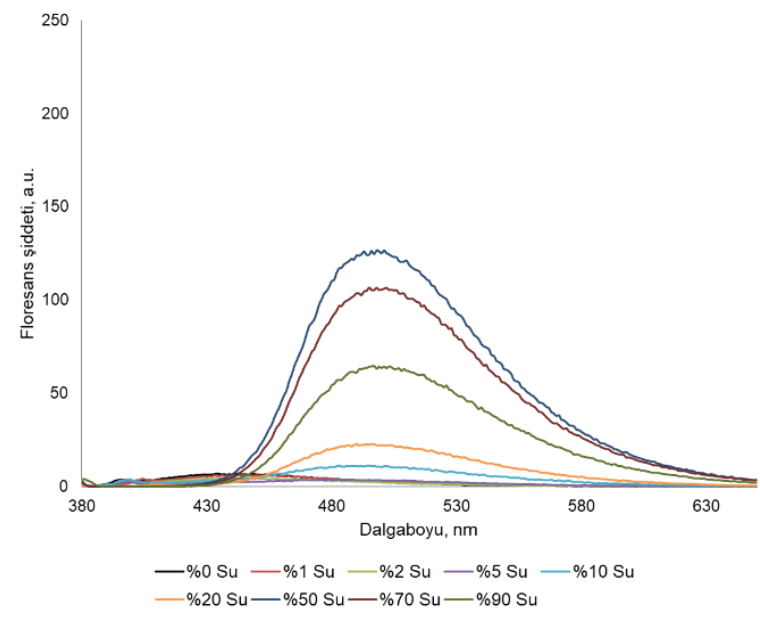

(a)

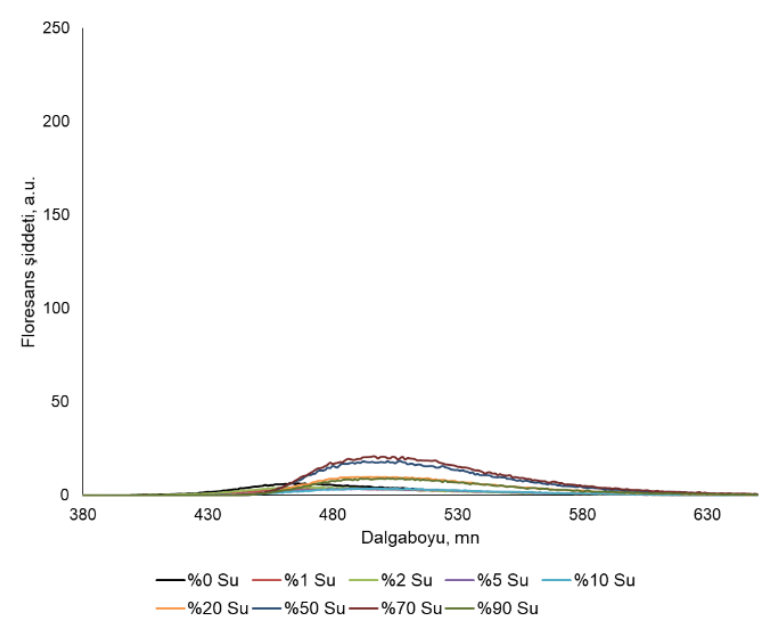

(c)

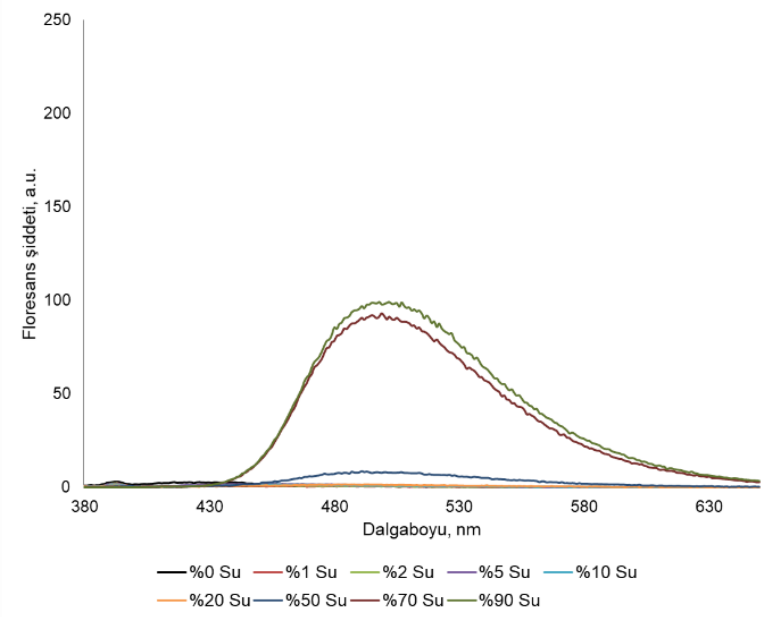

(b)

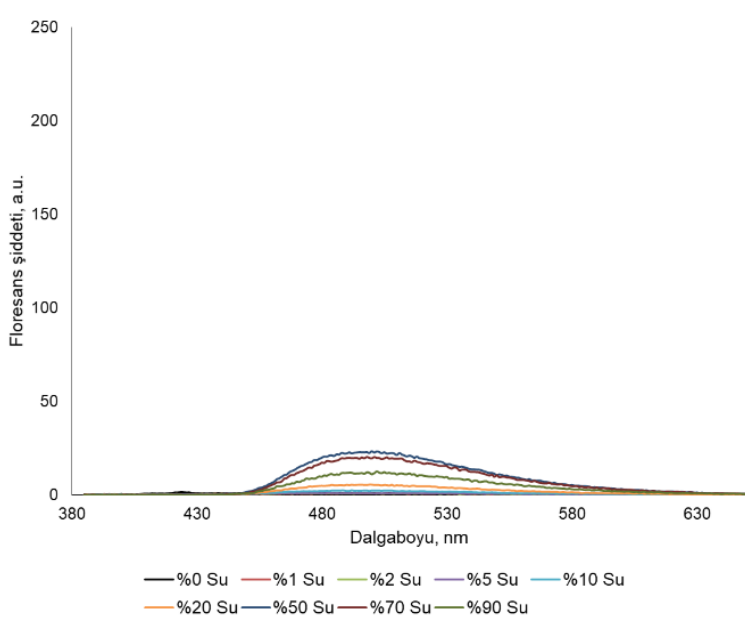

(d)

Şekil 2. (a) $\left[\mathrm{LH}_{2}\right]=2 \times 10^{-4} \mathrm{M}$ Etanol Emisyon Taramasl (b) $\left[\mathrm{LH}_{2}\right]=2 \times 10^{-4} \mathrm{M}$ Asetonitril Emisyon Taramasl (c) $\left[\mathrm{LH}_{2}\right]=2 \times 10^{-3} \mathrm{M}$ Etanol Emisyon Taramasl (d) $\left[\mathrm{LH}_{2}\right]=2 \times 10^{-3} \mathrm{M}$ Asetonitril Emisyon Taramasl (monokromotör slit aralıklarl; uyarma $=5 \mathrm{~nm}$, emisyon $=5 \mathrm{~nm}$ )

Etanol ortamında hazırlanmış $2 \times 10^{-4} \mathrm{M} \mathrm{LH}_{2}$ içeren çözeltilerde su içeriği arttıkça emisyon dalgaboyunun kırmızıya kayması ve floresans şiddetlerinin artması AIEE mekanizması ile açıklanabilir. Etanol, $\mathrm{LH}_{2}$ için orta kuvvette bir çözücü olduğundan ve su eklendikçe oluşan çözücü karışımının $\mathrm{LH}_{2}$ 'yi çözme gücü azaldığından çözelti ortamında liganda ait göz ile görülmeyen nanopartiküller oluştuğu düşünülmektedir [18]. Oluşan bu nano boyuttaki partiküllerin düzenli istiflenmesi, molekül içi dönmelerin kısıtlanması ve moleküller arası etkileşimlerden dolayı Schiff bazının daha düzlemsel bir geometride bulunması gibi etkilerin $\mathrm{LH}_{2}$ 'nin floresans özelliğinin 
artmasında etken olduğu söylenebilir [29]. Çözeltide su derişimi arttıkça nanopartikül oluşumu, dolayısıyla da yukarıda belirtilen etkiler arttığından \%50 oranında su içeren çözeltiye kadar, emisyon dalgaboyunda kırmızıya kayma ve floresans şiddetinde artma tespit edilmiştir (J-agregasyon). Ancak su oranı \%50'nin üzerine çıktığında agregasyonun hızlı olması nedeniyle istiflenme tipinin değişmesi (J-agregasyon $+\mathrm{H}$-agregasyon karışımı), fazla miktarda partikül oluşumundan dolayı moleküller arası çarpışmaların artması gibi nedenlerden dolayı floresansın sönümlendiği öne sürülebilir. Diğer bir ifadeyle, etanol ile hazırlanmış $2 \times 10^{-4} \mathrm{M} \mathrm{LH}_{2}$ içeren çözeltilerde su oranı \%1-50 arasında olduğunda çözeltilerde AIEE mekanizması geçerliyken, su miktarı \%70 ve 90 olan çözeltilerde ise ACQ mekanizmas1 etkin olduğu düşünülmektedir.

Tablo 4. Ön deneme çalışmalarında kullanılan farkl yüzdelerde su içeren çözeltilerin emisyon dalgaboyları

\begin{tabular}{|c|c|c|c|c|c|c|c|}
\hline \multicolumn{4}{|c|}{$\left[\mathrm{LH}_{2}\right]=2 \times 10^{-4} \mathrm{M}$} & \multicolumn{4}{|c|}{$\left[\mathrm{LH}_{2}\right]=2 \times 10^{-3} \mathrm{M}$} \\
\hline \multicolumn{2}{|c|}{ Etanol } & \multicolumn{2}{|c|}{ Asetonitril } & \multicolumn{2}{|c|}{ Etanol } & \multicolumn{2}{|c|}{ Asetonitril } \\
\hline $\begin{array}{c}\text { Su oranı } \\
(\%)\end{array}$ & $\begin{array}{c}\text { Emisyon } \lambda \\
(n m)\end{array}$ & $\begin{array}{c}\text { Su oranı } \\
(\%)\end{array}$ & $\begin{array}{c}\text { Emisyon } \lambda \\
(\mathrm{nm})\end{array}$ & $\begin{array}{c}\text { Su oranı } \\
(\%)\end{array}$ & $\begin{array}{c}\text { Emisyon } \lambda \\
(\mathrm{nm})\end{array}$ & $\begin{array}{c}\text { Su oranı } \\
(\%)\end{array}$ & $\begin{array}{c}\text { Emisyon } \lambda \\
(\mathrm{nm})\end{array}$ \\
\hline 0 & 442 & 0 & 428 & 0 & 464 & 0 & 465 \\
\hline 1 & 444 & 1 & 430 & 1 & 470 & 1 & 492 \\
\hline 2 & 448 & 2 & 445 & 2 & 477 & 2 & 492 \\
\hline 5 & 486 & 5 & 456 & 5 & 491 & 5 & 494 \\
\hline 10 & 493 & 10 & 465 & 10 & 498 & 10 & 496 \\
\hline 20 & 498 & 20 & 492 & 20 & 498 & 20 & 498 \\
\hline 50 & 498 & 50 & 498 & 50 & 498 & 50 & 498 \\
\hline 70 & 498 & 70 & 498 & 70 & 498 & 70 & 498 \\
\hline 90 & 498 & 90 & 498 & 90 & 498 & 90 & 498 \\
\hline
\end{tabular}

Diğer yandan, asetonitril $\mathrm{LH}_{2}$ için iyi bir çözücü olduğu için $\% 50$ oranında su eklenene kadar $2 \times 10^{-4}$ M'lık çözeltilerde ligandın çözünürlüğü yeteri kadar düşmediğinden yani belirli bir miktarda nanopartikül oluşumu meydana gelmediğinden floresans gözlenememiştir (Şekil 2b). Bir diğer neden de, \%50 su konsantrasyonuna kadar oluşan agregat tipinin farklılık göstermesi olabilir (Hagregasyon). Su oran $1 \% 50$ olduğunda yeteri miktar nanopartikül oluşumu ve/veya daha düşük su derişimlerinde oluşmuş olan nanopartikülerin istiflenme tipinin protik çözücünün artışı (su artışı) ile değişmesi (J-agregasyon oluşumu), şiddeti düşük olsa da bir emisyonun ortaya çıkmasını sağlamıştır. Su oranı $\% 70$ ve 90 çıkarıldığında ise asetonitrilli ligand çözeltisinin daha şiddetli bir floresans emisyonu verdiği görülmektedir. Ligand derişimi arttırıldığında $\left(2 \times 10^{-3} \mathrm{M}\right)$ ise her iki çözücü için de su eklenmesi emisyon şiddetinde kayda değer bir artışa neden olmamaktadır (Şekil 2c ve d). Derişik çözeltilerde oluşan agregatların birbirine çok yakın olması nedeniyle moleküller arası enerji transferinden, oluşan agregatların parçacık boyutunun büyümesinden (\%90 su içeren etanollü ve asetonitrilli çözeltilerde gözle görülür çökme olması) ve/veya oluşan agregatların istiflenme tipinin farklı olmasından dolayı floresansın sönümlenmesi bu sonucun sebebi olarak gösterilebilir.

$\mathrm{Bu}$ sonuçlara göre, AIEE mekanizmasını en iyi etanol ile hazırlanmış $2 \times 10^{-4} \mathrm{M} \mathrm{LH}_{2}$ çözeltisi göstermiş, eklenen su miktarı arttıkça floresans şiddetinin orantılı olarak arttı̆̆ görülmüştür. Uyarma dalgaboylarındaki kayma \%50 su içeren çözeltilerden sonra sabit kaldığından bundan sonraki çalışmalarda uyarma dalgaboyu olarak $375 \mathrm{~nm}$ kullanılmıştır.

\section{B. ZAMAN ETKİSI}

Ön deneylerde, etanol ortamında hazırlanmış $2 \times 10^{-4} \mathrm{M} \mathrm{LH}_{2}$ içeren çözeltilerin hazırlandıktan 30 dakika sonra alınan emisyon spektrumlarında (Şekil 2a) su derişimi arttıkça emisyon dalgaboyunun kırmızıya kaymasıyla beraber çözeltilerin floresans şiddetinin de arttığı (\%10-50 arasında) tespit 
edilmiş ve bu artışın sebebi olarak AIEE mekanizması öne sürülmüştür. Daha düşük su içeriğine (\%110) sahip çözeltilerde ise bir miktar kırmızıya kayma gözlense de floresans şiddetlerinde yeterince artış olmaması bu çözeltilerdeki agregasyon hızının daha düşük olduğunu düşündürmektedir. $\mathrm{Bu}$ sebeple, farklı derişimde su içeren (\%1-50) bir seri $\mathrm{LH}_{2}$ çözeltisi $\left(2 \times 10^{-4} \mathrm{M}\right.$, etanolde) tekrardan hazırlanmıştır. Bu çözeltiler hazırlandıktan 1, 2, 3, 4 ve 24 saat sonra $375 \mathrm{~nm}$ dalgaboyunda uyarılarak gösterdikleri emisyonlar ölçülmüştür (Şekil 3 ve 4). Düşük konsantrasyonda su içeren çözeltilerin (\%1-10) emisyon şiddetleri az olduğundan duyarlılı̆g 1 artırmak için uyarma ve emisyon monokromotör slit aralıkları $10 \mathrm{~nm}$ 'ye ayarlanmıştır. Diğer yandan, \%10-50 aralığındaki çözeltiler daha şiddetli floresans özellik gösterdiğinden emisyon şiddetinin cihazın üst tayin sınırı olan 1000 a.u. değerini geçmemesi için uyarma monokromotör slit aralığ $5 \mathrm{~nm}$, emisyon slit aralığ ayarlanarak ölçümler alınmıştır.

Şekil 3'den de görüldüğü üzere su içeriği \%1-10 olan çözelti serisinin hazırlandıktan 1 saat sonra yapılmış olan emisyon ölçümlerinde $(\lambda e x=375 \mathrm{~nm}) \% 1$ su içeriğine sahip çözelti $461 \mathrm{~nm}$ dalgaboyunda maksimum floresans şiddeti (52 a.u.) göstermiştir (Şekil 3a). Çözeltilerde su içeriği arttıkça kırmızıya kayma tespit edilmiş ve emisyon şiddetlerinde artış gözlenmiştir. Bu serinin en derişik çözeltisi olan \%10'luk sulu çözeltinin emisyon dalgaboyu üç saatin sonunda 498 nm'ye kaymış (Şekil 3c) ve 24 saatin sonunda da aynı dalgaboyunda 156 a.u. şiddetinde emisyon vermiştir (Şekil 3e). Zaman ilerledikçe bu serideki \%1'lik hariç tüm sulu çözeltilerin maksimum emisyon dalgaboyları 498 nm'ye kaymış ve emisyonları şiddetlenmiştir. 24 saat sonunda \%10 su içeren çözeltinin emisyon şiddeti 486 a.u.'ya ulaşmıştır (Şekil 3e). Serinin en seyreltik çözeltisi olan \%1'lik çözeltinin maksimum emisyon dalgaboyu ise bu süre sonunda $481 \mathrm{~nm}$ ye kaymış ve şiddeti ilk 1 saate göre yaklaşık iki kat artarak 108 a.u. değerine ulaşmıştır. Bu çözeltinin emisyon dalgaboyunun serideki diğer çözeltiler (\%2-10) gibi 498 nm'ye kaymaması, su miktarının düşük olması dolayısıyla da çözeltideki nanopartiküllerin az oluşmasından kaynaklandığı düşünülmektedir. Bu orandaki su miktarı ancak floresans dalgaboyunu ancak yaklaşık 481 nm’ye kadar kaydırabilmiştir.

Su içeriği \%10-50 olan çözelti serisi incelendiğinde farklı bir davranış ile karşılaşılmaktadır (Şekil 4). İlk bir saatte $\% 10$ ve 20 sulu çözeltilerin maksimum emisyon verdikleri dalgaboyu sırasıyla 495 ve $497 \mathrm{~nm}$ olarak bulunmuş diğer çözeltiler ise bu zaman sonunda $498 \mathrm{~nm}$ 'de emisyon vermiştir (Şekil 4a). İkinci saatin sonunda \%20'lik, üçüncü saatin sonunda ise \%10'luk çözeltinin emisyonu 498 nm'ye ulaşmıştır (Şekil 4b ve c). Diğer yandan, \%30-50 su içeren çözeltiler ilk bir saatte 498 nm'de şiddetli floresans vermiş olup zaman ilerledikçe dalgaboyunda herhangi bir kayma gözlenmemiştir, ancak, floresans şiddetlerinde bir miktar düşme tespit edilmiştir. Örneğin, ilk saatin sonunda \%50 su içeren çözeltinin floresans şiddeti 641 a.u. (Şekil 4a) iken 24 saatin sonunda 507 a.u.'luk (Şekil 4e) bir şiddette emisyon göstermiştir.

Şekil 5a ve b tüm çözeltilerin 1, 2, 3, 4 ve 24 saat sonunda $498 \mathrm{~nm}$ 'de verdiği emisyon şiddetlerinin grafiğe geçirilmesi ile oluşturulan zaman-floresans şiddeti eğrilerini göstermektedir. Şekil 5a'ya göre \%1-10 su içeren çözeltilerin floresans şiddetleri ilk dört saat içinde daha hızlı artmış sonrasında artış hızı yavaşlayarak devam etmiştir. Bu durumun sebebi, çözeltilerdeki su derişimlerinin görece olarak daha az olması dolayısıyla da agregasyon oluşumunun zaman almasıdır. Şekil 5b'ye göre \%10 ve 20 su içeren çözeltiler de aynı eğilimi göstermiş, ancak, üçüncü saatten sonra floresans şiddetlerinde artış çok az olmuştur. Diğer yandan, su içeriği \%30-50 olan çözeltilerin ilk saatte maksimum emisyon şiddeti göstermesi sonrasında bir miktar düşmesi ve 4-24 saat arasında dengeye gelmesi davranışı bu çözeltilerin diğer çözeltilere göre daha derişik su içermesinden dolayıdır. Bu çözeltilerde agregasyon oluşumu çok hızlı olmakta daha sonra moleküller arası etkileşmeler (örneğin çarpışmalar) nedeniyle enerji transferi meydana gelmekte ve floresans sönümlenmektedir. Ancak dördüncü saatten sonra bu çözeltilerin denge durumuna ulaştığı göze çarpmaktadır. 


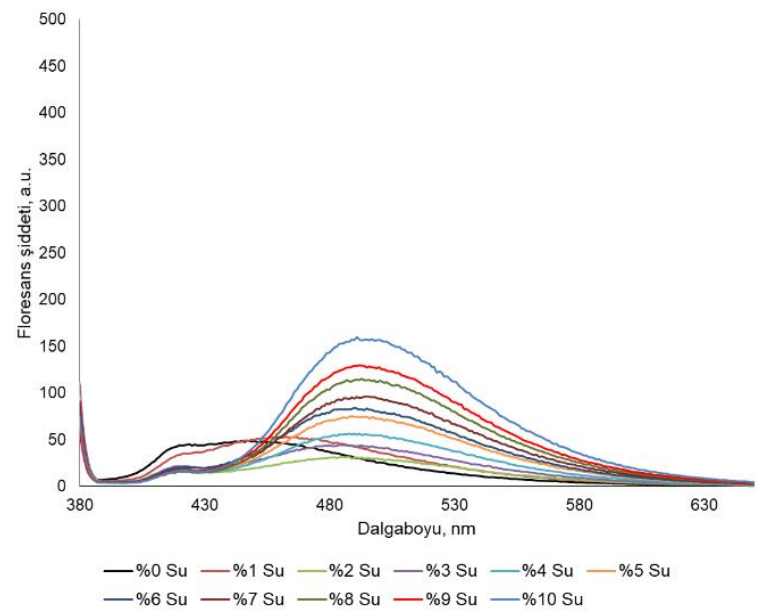

(a)

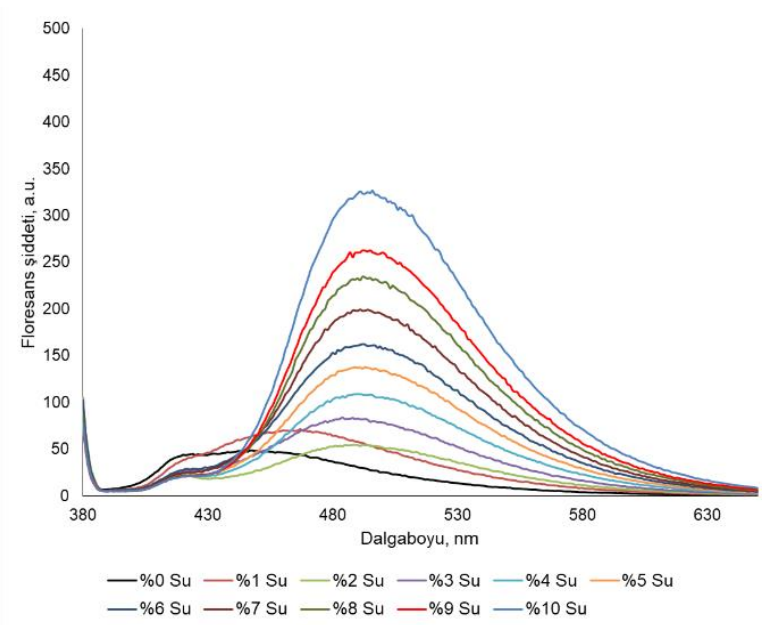

(c)

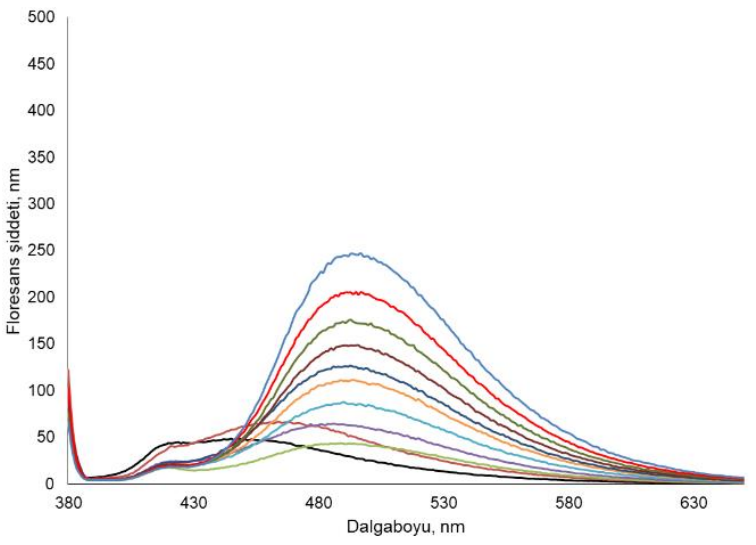

- $\% 0 \mathrm{Su}-\% 1 \mathrm{Su}-\% 2 \mathrm{Su}-\% 3 \mathrm{Su}-\% 4 \mathrm{Su}-\% 5 \mathrm{Su}$ - $\% 6$ su $-\% 7$ su $-\% 8$ su $-\% 9$ su $-\% 10$ su

(b)

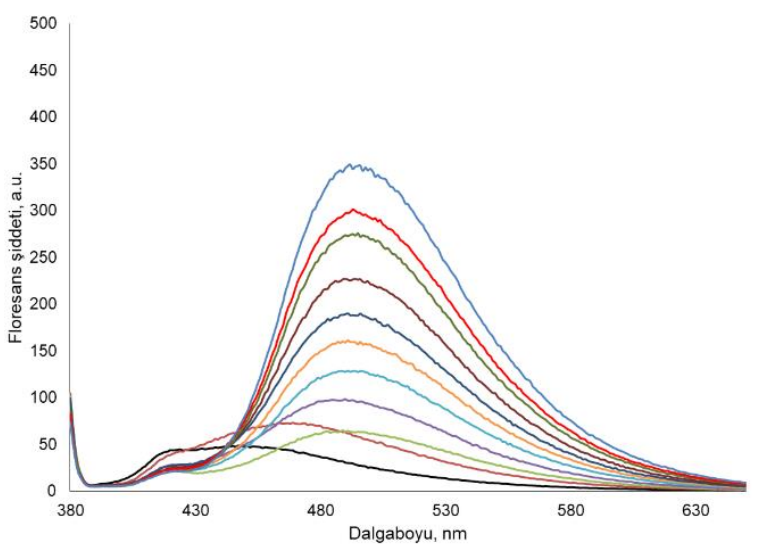

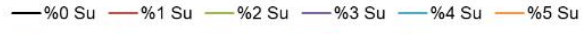
- $\% 6 \mathrm{Su}$ - $\% 7 \mathrm{Su}$ - $\% 8 \mathrm{Su}$ - $\% 9 \mathrm{Su}-\% 10 \mathrm{Su}$

(d)

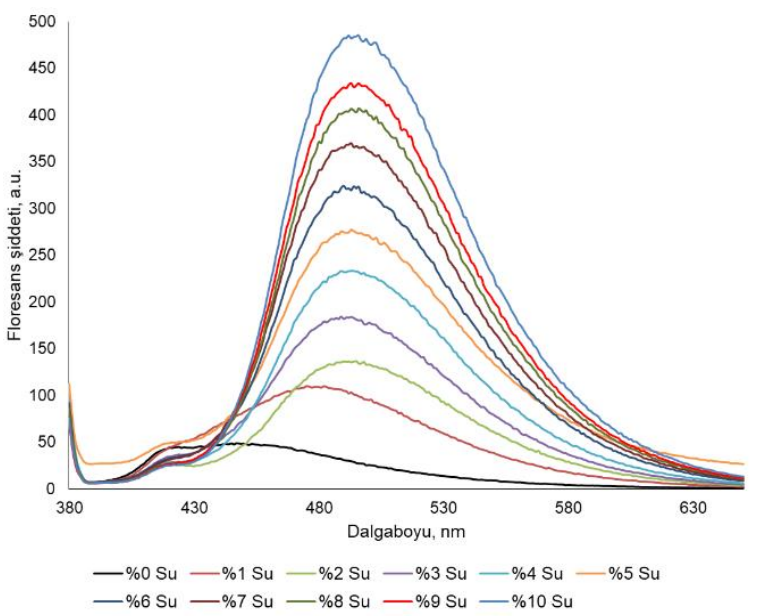

(e)

Şekil 3. $\left[\mathrm{LH}_{2}\right]=2 \times 10^{-4} \mathrm{M}$ Etanol $[\mathrm{Su}]=\% 0-10$ Zamana Bağlı Emisyon Taramasl (a) 1 Saat (b) 2 Saat (c) 3 Saat (d) 4 Saat (e) 24 Saat $\left(\lambda_{e x}=375 \mathrm{~nm}\right.$; monokromotör slit aralıklarl uyarma $=10 \mathrm{~nm}$ emisyon $\left.=10 \mathrm{~nm}\right)$ 


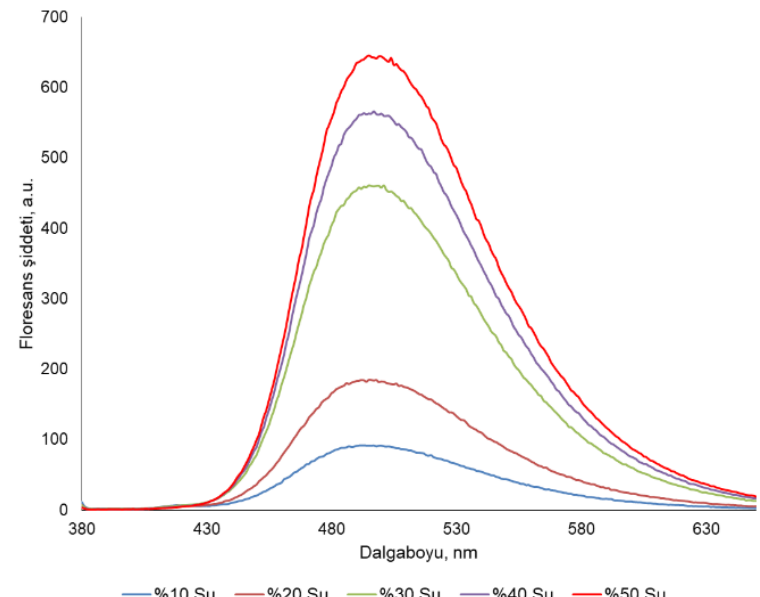

(a)

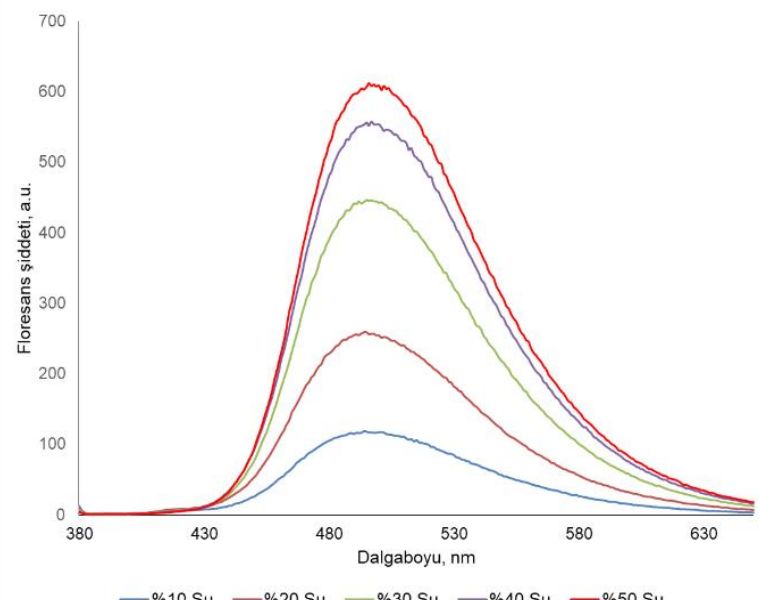

(c)

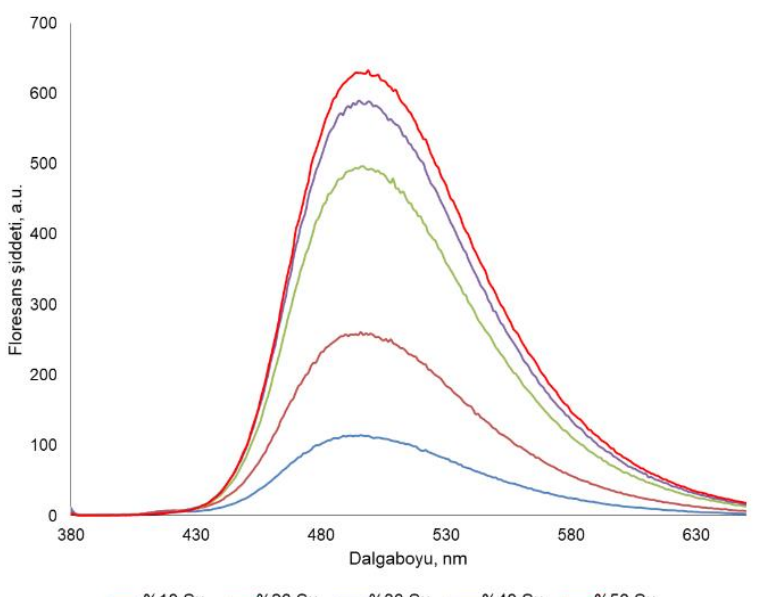

(b)

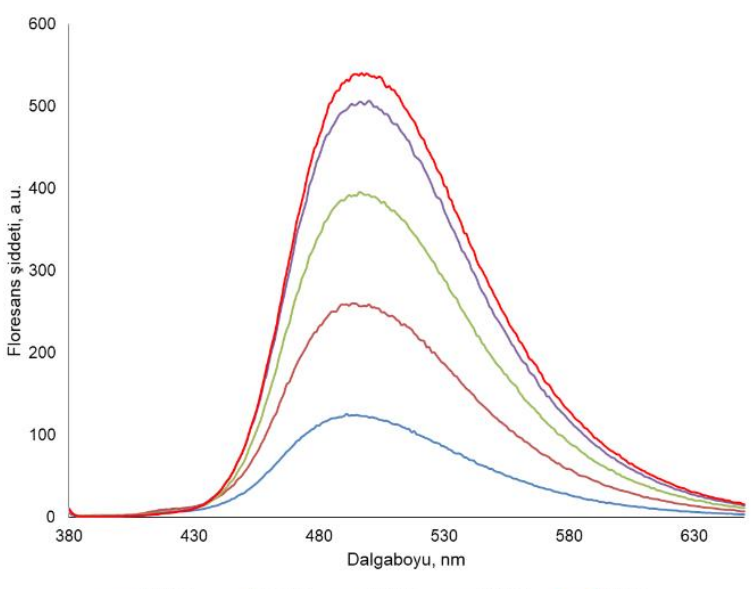

(d)

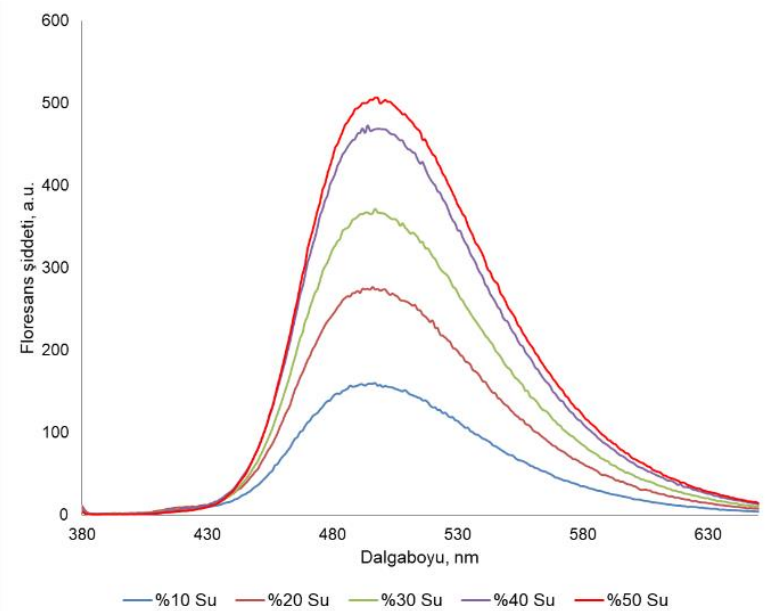

(e)

Şekil 4. $\left[\mathrm{LH}_{2}\right]=2 \times 10^{-4} \mathrm{M}$ Etanol [Su] = \%10-50 Zamana Bağll Emisyon Taraması (a)1 Saat (b) 2 Saat (c) 3 Saat (d) 4 Saat (e) 24 Saat $\left(\lambda_{e x}=375 \mathrm{~nm}\right.$; monokromotör slit aralıklarl uyarma $=5 \mathrm{~nm}$ emisyon $\left.=10 \mathrm{~nm}\right)$ 


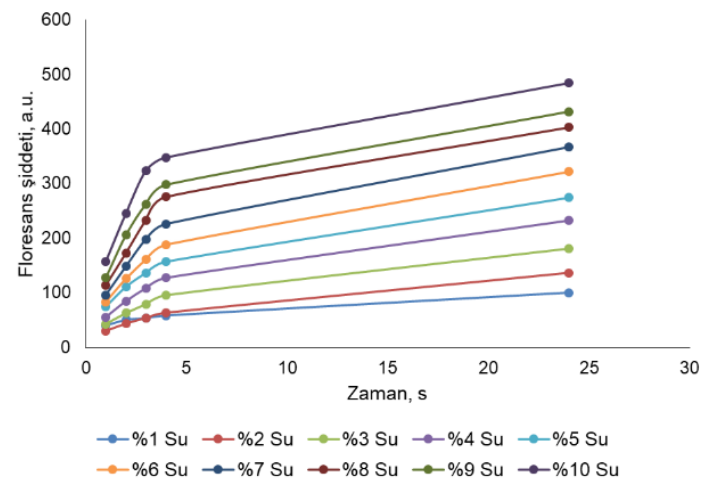

(a)

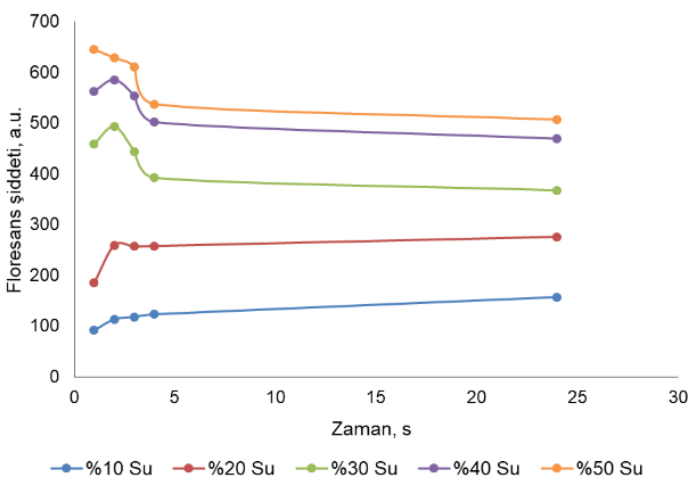

(b)

Şekil 5. Floresans Şiddetinin Zamanla Değişimi (1-24 Saat) $\left(\lambda_{e x}=375 \mathrm{~nm}, \lambda_{e m}=498 \mathrm{~nm}\right)$ (a) $\left[\mathrm{LH}_{2}\right]=2 \times 10^{-4} \mathrm{M}$ Etanol $[\mathrm{Su}]=\% 1-10($ monokromotör slit aralıklarl; uyarma $=10 \mathrm{~nm}$, emisyon $=10 \mathrm{~nm})$ (b) $\left[\mathrm{LH}_{2}\right]=2 \times 10^{-4} \mathrm{M}$ Etanol $[\mathrm{Su}]=\% 10-50$ (monokromotör slit arallklarl; uyarma $=5 \mathrm{~nm}$, emisyon $\left.=10 \mathrm{~nm}\right)$

\section{KALİBRASYON GRAFİKLERİ}

Etanol ortamında hazırlanmış $2 \times 10^{-4} \mathrm{M} \mathrm{LH}_{2}$ içeren \%1-50 sulu çözeltilerin zamana bağlı floresans şiddetlerinin ölçümü çalışmasından sonra, bu çözeltilerin kalitatif ve kantitatif su tayininde kullanılabilirliği incelenmiştir. Kimyasal analizlerde ve/veya sentezlerde kullanılan etanolün çoğu zaman yüksek saflıkta olması istenmektedir. Çözücünün saflığını düşüren en önemli unsurlardan birisi çözücünün içerisindeki su miktarıdır. Buna göre, kimyasal işlemler sırasında kullanılacak olan etanolün içerisinde su olup olmaması, var ise miktarının tespiti için $\mathrm{LH}_{2}$ 'nin kullanılabileceği düşünülmektedir. Bunun için, $\mathrm{LH}_{2}$ 'nin su safsızlı̆̆ 1 bilinmeyen etanol ile $2 \times 10^{-4} \mathrm{M}^{\prime} l 1 \mathrm{k}$ çözeltisi hazırlanmalıdır. Zaman grafiklerine göre (Şekil $5 \mathrm{a}$ ve b) 24 saat beklenmeli (özellikle düşük su içeriği olması ihtimaline karş1) ve floresans spektrometresi ile $375 \mathrm{~nm}$ uyarma dalgaboyunda emisyon spektrumu alınmalıdır. Çözeltinin maksimum emisyon dalgaboyunun, saf etanolün $(\% 0 \mathrm{su})$ emisyon dalgaboyundan (442 nm) daha yüksek çıkması etanolün içinde su varlığını gösterir (kalitatif analiz). Su miktarı tayini yapabilmek için kalibrasyon grafikleri çizilmeli, su konsantrasyonu ile floresans şiddeti arasında doğrusal bir ilişki bulunmalıdır. Bu amaçla, \%1-50 su içeriğine sahip çözeltilerin, hazırlandıktan 24 saat sonra, emisyon spektrumları alınmıştır $\left(\lambda_{\mathrm{ex}}=375 \mathrm{~nm}, \% 1-10\right.$ serisi için uyarma ve emisyon monokromotör slit aralıkları $10 \mathrm{~nm}$, \%10-50 serisi için monokromotör slit aralıkları uyarma $=5 \mathrm{~nm}$, emisyon $=10 \mathrm{~nm}$ ). Her bir çözeltinin $498 \mathrm{~nm}$ 'de verdiği emisyon şiddeti ölçülerek su derişimine karşı grafiğe geçirilmiştir. Elde edilen kalibrasyon grafikleri Şekil 6'da verilmiştir. \%50 su içeren çözelti doğrusallıktan saptığı için kalibrasyon grafiğine dahil edilmemiştir (Şekil 6b). Her iki seri için çizilen kalibrasyon grafiklerinin $\mathrm{R}^{2}$ değerleri 0,99 'dan büyük olduğundan çalışma aralığının doğrusallığı kantitatif tayin için uygundur.

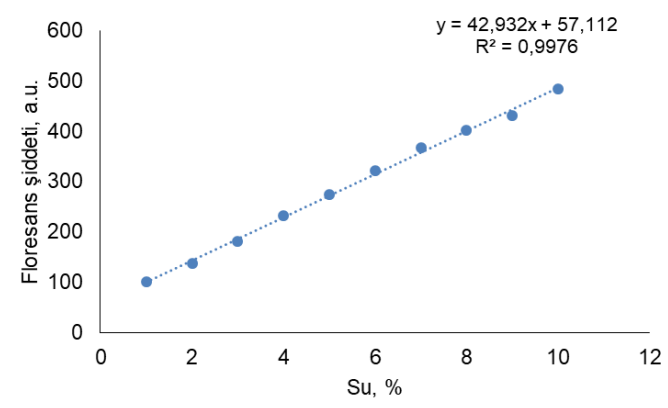

(a)



(b)

Şekil 6. Kalibrasyon grafikleri $(\boldsymbol{a})\left[\mathrm{LH}_{2}\right]=2 \times 10^{-4} \mathrm{M}$ Etanol $[\mathrm{Su}]=\% 1-10$ (monokromotör slit aralıklarl; uyarma $=10 \mathrm{~nm}$, emisyon $=10 \mathrm{~nm}(\boldsymbol{b})\left[\mathrm{LH}_{2}\right]=2 \times 10^{-4} \mathrm{M}$ Etanol $[\mathrm{Su}]=\% 10-50$ ( monokromotör slit aralıklarl; uyarma $=5 \mathrm{~nm}$, emisyon $=10 \mathrm{~nm})(24$ Saat $)$ 


\section{IV.SONUC}

Yapılan çalışmalar sonucunda, $\mathrm{LH}_{2}$ 'nin etanol ortamında hazırlanmış $2 \times 10^{-4}$ M'lık çözeltisinin floresans özelliğinin farklı su derişimlerinde (\%1-50) arttığ 1 , maksimum emisyon dalgaboyunun da kırmızıya kaydığı bulunmuştur. Bu şiddet artışının ve dalgaboyu kaymasının su eklenmesi ile birlikte çözelti ortamında agregasyon oluşumundan kaynaklandığı tespit edilmiştir. Bunun yanı sıra, çözeltideki agregasyon oluşumunun dolayısıyla da ligandın floresans özelliğinin düşük su derişimlerinde zamanla arttığı görülmüştür. Bütün çözeltilerin aynı zamanda emisyon spektrumları alındığında çözeltilerdeki su derişimi ile $\mathrm{LH}_{2}$ 'nin floresans cevabı arasında doğrusal bir ilişki bulunmuştur. Neticede, etanolün içinde su varlığı kalitatif olarak dalgaboyundaki kırmızıya kaymadan, kantitatif olarak ise kalibrasyon grafiğginden tespit edilebileceği ortaya konulmuştur.

\section{KAYNAKLAR}

[1] C. Fana, J. Pei, J. Zhao, M. Huang, W. Tang, J. Hu, B. Cao, H. Tan, S. Tao and C. Yang, “A yellow organic emitter with novel D-A3 architecture and hidden delayed fluorescence for highly efficient monochromatic OLEDs," Organic Electronics, vol. 73, pp. 102-108, 2019.

[2] B. Huang, Y. Ji, Z. Li, N. Zhou, W. Jiang, Y. Feng, B. Lin and Y. Sun, "Simple aggregationinduced delayed fluorescence materials based on anthraquinone derivatives for highly efficient solution-processed red OLEDs," Journal of Luminescence, vol. 187, pp. 414-420, 2017.

[3] A. Paun, N.D. Hadade, C.C. Paraschivescu and M. Matache, "1,3,4-Oxadiazoles as luminescent materials for organic light emitting diodes via cross-coupling reactions," Journal of Materials Chemistry C, vol. 4, pp. 8596-8610, 2016.

[4] Z. Ma, X. Wang, C. Wang, X. Chen and Q. Lv, "A sensitive and selective fluorescence probe for detection of hypochlorite ( $\mathrm{OCl}-)$ and its bioimaging in live cells," Spectrochimica Acta Part A: Molecular and Biomolecular Spectroscopy, vol. 213, pp. 370-374, 2019.

[5] L. Jin, W. Wang, Z. Shen, J. Xu, Q. Wang and C. Zhao, "A new coumarin-based fluorescence "turn-on" sensor for Al(III) ions and its bioimaging in cell," Journal of Molecular Structure, vol. 1197, pp. 73-79, 2019.

[6] F. Huo, Z. Kanga, M. Zhu, C. Tan, Y. Tang, Y. Liu and W. Zhang, "Metal-triggered fluorescence enhancement of multicolor carbon dots in sensing and bioimaging," Optical Materials, vol. 94, pp. 363-370, 2019.

[7] R. Bandi, R. Dadigala, B.R. Gangapuram and V. Guttena, "Green synthesis of highly fluorescent nitrogen - doped carbon dots from Lantana camara berries for effective detection of lead(II) and bioimaging," Journal of Photochemistry \& Photobiology, B: Biology, vol. 178, pp. 330$338,2018$.

[8] F. Jina, T. Lu, P. Wang, Z. Rong, X. Wu, L. Qiao, Y. Liu, R. Liao and D. Tao, "Crystal structures, two-photon excited fluorescence and bioimaging of $\mathrm{Zn}(\mathrm{II})$ complexes based on $\mathrm{D}-\pi$-A structural triphenylamine derivative," Journal of Luminescence, vol. 192, pp. 1127-1132, 2017.

[9] J. Xu, N. Liu, C. Hao, Q. Han, Y. Duan and J. Wu, "Novel fluorescence "on-off-on" peptidebased chemosensor for simultaneous detection of $\mathrm{Cu}^{2+}, \mathrm{Ag}^{+}$and $\mathrm{S}^{2-}$," Sensors and Actuators B: Chemical, vol. 280, pp. 129-137, 2019. 
[10] X. Gong, H. Zhang, N. Jiang, L. Wang and G. Wang, "Oxadiazole-based 'on-off' fluorescence chemosensor for rapid recognition and detection of $\mathrm{Fe}^{2+}$ and $\mathrm{Fe}^{3+}$ in aqueous solution and in living cells," Microchemical Journal, vol. 145, pp. 435-443, 2019.

[11] Q. Wu, K. Wang, Z. Wang, Y. Sun, D. Cao, Z. Liu, R. Guan, S. Zhao and X. Yu, "Two 3hydroxyflavone derivatives as two-photon fluorescence turn-on chemosensors for cysteine and homocysteine in living cells," Talanta, vol. 181, pp. 118-124, 2018.

[12] E. Ergun, Ü. Ergun, Ö. İleri and M.F. Küçükmüzevir, "An investigation of some Schiff base derivatives as chemosensors for $\mathrm{Zn}(\mathrm{II})$ : the performance characteristics and potential applications," Spectrochimica Acta Part A: Molecular and Biomolecular Spectroscopy, vol. 203, pp. 273-286, 2018.

[13] P. A. More and G. S. Shankarling, "Reversible 'turn off' fluorescence response of $\mathrm{Cu}^{2+}$ ions towards 2-pyridyl quinoline based chemosensor with visible colour change," Sensors and Actuators B: Chemical, vol. 241, pp. 552-559, 2017.

[14] J. Qi, X. Hu, X. Dong, Y. Lu, H. Lu, W. Zhao and W. Wu, "Towards more accurate bioimaging of drug nanocarriers: turning aggregation-caused quenching into a useful tool," Advanced Drug Delivery Reviews, vol. 143, pp. 206-225, 2019.

[15] Y. Huang, J. Xing, Q. Gong, L. Chen, G. Liu, C. Yao, Z. Wang, H. Zhang, Z. Chen and Q. Zhang, "Reducing aggregation caused quenching effect through co-assembly of PAH chromophores and molecular barriers," Nature Communications, vol. 10, pp. 169-178, 2019.

[16] T. Forster and K. Kasper, "Ein konzentrationsumschlag der fluoreszenz des pyrens," Zeitschrift für Elektrochemie, vol. 59, pp. 976-980, 1955.

[17] J. B. Birks, Photophysics of Aromatic Molecules, 1st ed., London, England: WileyInterScience, 1970, pp. 704.

[18] J. Luo, Z. Xie, J. W. Y. Lam, L. Cheng, H. Chen, C. Qiu, H. S. Kwok, X. Zhan, Y. Liu, D. Zhuc and B. Z. Tang, "Aggregation-induced emission of 1-methyl-1,2,3,4,5-pentaphenylsilole," Chemical Communications, vol. 21, pp. 1740-1741, 2001.

[19] M. F. Küçükmüzevir, Ö. İleri, E. Ergun ve Ü. Ergun, "ONNO tipi bir Schiff bazı ve indirgenmiş türevinin çeşitli metallerle yaptığı komplekslerin floresans özelliklerinin incelenmesi," Düzce Üniversitesi Bilim ve Teknoloji Dergisi, c. 4, ss. 862-872, 2016.

[20] B. Zeybek, B. Meltem Ateş, F. Ercan, M. Levent Aksu, E. Kılıç and O. Atakol, "The effect of ligand basicity on the thermal stability of heterodinuclear NiII-ZnII complexes," Journal of Thermal Analysis and Calorimetry, vol. 98, pp. 377-385, 2009.

[21] P. Yadava, A. K. Singh, C. Upadhyay and V. P. Singh, "Photoluminescence behaviour of a stimuli responsive Schiff base: aggregation induced emission and piezochromism," Dyes and Pigments, vol. 160, pp. 731-739, 2019.

[22] S. S. Pasha, H. R. Yadav, A. R. Choudhury and I. R. Laskar, "Synthesis of an aggregationinduced emission (AIE) active salicylaldehyde based Schiff base: Study of mechanoluminescence and sensitive Zn(II) sensing," Journal of Materials Chemistry C, vol. 5, pp. 9651-9658, 2017.

[23] F. Wu, G. Xu, X. Zeng, L. Mu, C. Redshaw and G. Wei, "Characterization of the aggregationinduced enhanced emission of N,N'-bis(4-methoxysalicylide)benzene-1,4-diamine," Journal of Fluorescence, vol. 25, pp. 1183-1189, 2015. 
[24] M. Shellaiah, Y. H. Wu, A. Singh, M. V. Ramakrishnam Raju and H. C. Lin, "Novel pyreneand anthracene-based Schiff base derivatives as $\mathrm{Cu}^{2+}$ and $\mathrm{Fe}^{3+}$ fluorescence turn-on sensors and for aggregation induced emissions," Journal of Materials Chemistry A, vol. 1, pp. 1310-1318, 2013.

[25] X. F. Li, Z. G. Chi, B. J. Xu, H. Y. Li, X. Q. Zhang, W. Zhou, Y. Zhang, S. W. Liu and J. R. $\mathrm{Xu}$, "Synthesis and characterization of triphenylethylene derivatives with aggregation-induced emission characteristics," Journal of Fluorescence, vol. 21, pp. 1969-1977, 2011.

[26] W. Tang, Y. Xiang, and A. Tong, "Salicylaldehyde azines as fluorophores of aggregationinduced emission enhancement characteristics," The Journal of Organic Chemistry, vol. 74, pp. 2163 2166, 2009.

[27] M. Más-Montoya and R. A. J. Janssen, "The effect of $\mathrm{H}$ - and J-Aggregation on the photophysical and photovoltaic properties of small thiophene-pyridine-DPP molecules for bulkheterojunction solar cells," Advanced Functional Materials, vol. 27, pp. 1605779, 2017.

[28] Z. Arsov, I. Urbančič and J. Štrancar, "Aggregation-induced emission spectral shift as a measure of local concentration of a $\mathrm{pH}$-activatable rhodamine-based smart probe," Spectrochimica Acta Part A: Molecular and Biomolecular Spectroscopy, vol. 190, pp. 486-493, 2018.

[29] N. Miengmern, A. Koonwong, S. Sriyab, A. Suramitr, R. P. Poo-arporn, S. Hannongbua and S. Suramitr, "Aggregation-induced emission enhancement (AIEE) of N,N'-Bis(Salicylidene)-pphenylenediamine Schiff base: synthesis, photophysical properties and its DFT studies," Journal of Luminescence, vol. 210, pp. 493-500, 2019. 